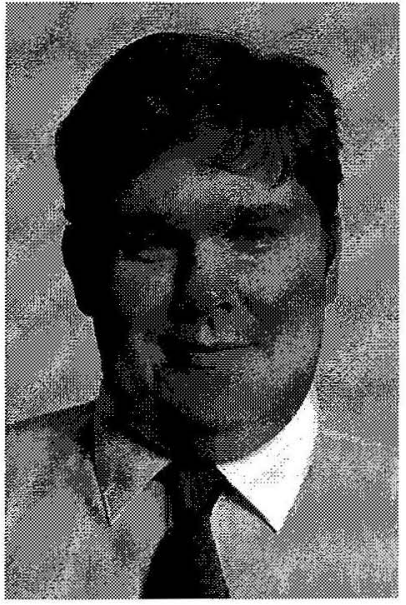

\title{
DAIRYING AND EMPLOYMENT IN THE AMURI: 1983 TO 2002
}

\author{
Reuben J. Edkins and \\ Rupert S. Tipples \\ Farm Management \\ Applied Management and Computing \\ Division \\ Lincoln University
}

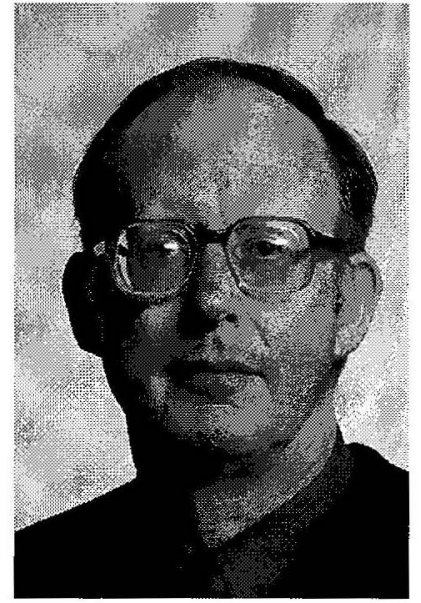

\begin{abstract}
The dairy industry is currently experiencing a staff shortage, as are many other industries. It has experienced rapid expansion, and the situation is made worse by the poor image of the industry. This expansion has often occurred in areas with little prior dairying. The Amuri region, North Canterbury, is one such area. The conversion of farms to dairying began in 1983, following the commissioning of the 17000-hectare Waiau Plains Irrigation Scheme in 1980. There are now 49 herds in the area. Some of the initial dairy farming experiences were very bad, giving all dairying in the region a poor reputation. The Amuri region is 'geographically isolated basin', and situated approximately 90 minutes from Christchurch, with limited social opportunities for the farm staff. This resulted in extreme difficulties attracting and retaining good staff in the area. In response to this situation, the dairy farmers in the area formed the Amuri Dairy Employers Group, in March 2000. This group established a constitution including: Mandatory member employer training; Agreeing to an independent annual audit of member employment practices; and Agreeing to a Code of Practice for employment standards. I have undertaken a two-year investigation of the effects of the Amuri Dairy Employers Group, on dairy farming employment and the wider social effects in the Amuri area. A case-study approach has been used to gather the information. This research was conducted as part of a Masters of Commerce (Agriculture).
\end{abstract}

\section{Introduction}

The dairy industry faces a problem attracting and retaining sufficient numbers of adequately skilled staff currently. This state is being experienced by many industries at present and many regions have identified a shortage of skilled labour as one of the major limitations to economic growth and increasing productivity.

The New Zealand dairy farming industry has approximately 14,000 farmers with 3.45 million cows, producing 13 billion litres pf milk per year of which $95 \%$ is exported, and providing NZ\$ 7.5 billion in exports. This is some 2 percent of world production, which is 31 percent of world production traded across borders. New Zealand lowest cost producer of traded milk products. The Fonterra cooperative handles 96 percent of New Zealand production, which is 20 percent of New Zealand's total exports and 7 percent of national Gross Domestic Product (Fonterra, 2002).

\section{Estimates of Future Labour Needs}

There are two basic needs in terms of labour in the dairy industry. 1) On a simple numeric basis, far more people are required due to increasing farm numbers and the increasing size of these new farms. Gaul (2000), projected that between 1578 and 3960 extra staff would be required in the South Island by 2005 , depending on the efficiency ratios used. 2) Holmes and Cameron (2001) identified the need for higher levels of education among people in the dairy industry. The current percentage of dairy farm workers with degrees is $4 \%$, in the general population it is $8 \%$ and among 'managers' $12 \%$, which is an indication of the lower academic levels among dairy farm workers (as of 1999). Also they estimated the need for people with higher education levels as: 8,000 graduates on farm, 20,000 apprentices on farm, 250 agricultural post-graduates as consultants, and $100 \mathrm{PhD}$ graduates as researchers; all needed by 2030 . These are the only estimations which exist. No robust projections for staffing requirements for the dairy industry have been found.

\section{The Industry}

The dairy industry's' staffing situation is made worse by the industry's poor image, and the industry's rapid growth. The "urbanization" of society is also playing its part in reducing the potential pool of employees available in rural areas. Much of the industry expansion is occurring in new areas, areas where there has not been previous or recent dairy activity. These areas are not accustomed to dairying and dairy farmers. The social changes associated with a large scale changing to dairy farming are significant. Some of the 
advantages are: the increase in numbers of people, which often increases school roles, and increases spending in local shops and businesses. Disadvantages include the increased mobility of dairy farmers. Sharemilkers for example, are commonly on three-year contracts, moving to a new job in a new area after three years. This "instability" can often cause problems with reduced opportunities to develop social networks and reduced social involvement. They often foresee only short-term involvement with both the job and the area. The numeric increases in the school roles are often upset by the comings and goings of dairy farm pupils mid way through the academic year, at about $1^{\text {st }}$ of June. In areas of traditional inter-generational ownership transfer, people changing properties every three years is very short-term.

The research occurred over two seasons of record payouts, reaching $\$ 5.33$ per $\mathrm{kgMS}$ for the 2001/2002 season. The payout for Fonterra suppliers has dropped this season to $\$ 3.70 / \mathrm{kgMS}$, which will put significant pressure on farm profitability and in turn wages for farm workers. Any attempt to lower wages, with the drop in profitability, is not likely to be well received. There are no actual figures on wage levels, and whether any actual increase occurred is a matter of speculation. Anecdotally, wages have risen markedly in the last two years, which many people believe is linked to profitability.

The dairy farm season runs $1^{\text {st }}$ June to $31^{\text {st }}$ May the following year, with most employment and land purchase contracts working to these dates. Workload, during June and July is at its lowest. The spring period, involving calving, raising calves, moving through into the breeding season and irrigation is the period of highest workload. The late spring/early summer period is often monotonous, with repetitive jobs, coupled with the long hours. From Christmas to drying off, the hours steadily decrease and milkings becoming quicker. Thus employees begin a job at the period of lowest workload, and at a time when the opportunity to learn 'normal farm routines' is in short supply. Then suddenly the farm system moves into a period of very high workloads, when the opportunity to train someone and for an employee to learn steadily is minimal. For this reason, some farmers are moving to taking on inexperienced staff in February, to give them a more steady and realistic introduction into dairy farming.

\section{Background to the Amuri}

The Amuri region is a geographically isolated dry basin, 90 minutes northwest of Christchurch. The Weka Pass separates the basin from any centres of large population. This makes the area seem more isolated. The Waiau Plains Irrigation scheme had been built in the late 1970's, in response to drought and was initially seen as no more than 'insurance' against drought. The investigative work, prior to the construction of the scheme, was carried out on the expectation of an intensification of current land uses, i.e. carrying more sheep, and growing more reliable crops. The scheme was commissioned in 1980 , and little was done differently in terms of farming practices until 1983, when the first farm was converted to dairying. Several people I spoke to from the region said that following the commissioning of the irrigation scheme. "They had it, and it took them a while to work out what they were going to do with it." (Interview with Mr R. Davison, August 2002).

Interestingly, it was a local shoep farmer who converted his property first. Another interesting 'side-effect' of the irrigation scheme was that with the farmers undertaking the on-farm irrigation development works required, many of them borrowed to do this, bringing debt to the area. Several of the community members I spoke with, suggested that prior to the irrigation developments, there was little debt carried in the area. The effect of this is that in years of low return, where previously just operating costs had to be met, a reduction in personal income could cover the shortfall. Now large debt servicing costs also had to be met. To cover this many farmers had to adopt more 'robust' farming systems, with increased reliability of returns.

In 1984 "Rogernomics" began. The key policy changes in terms of dairying were, the floating of the New Zealand dollar, the removal of agricultural subsidies, and deregulation of several key agricultural markets. The results were, a sharp decline in agricultural products prices and a massive increase in interest rates.

During the late 1980s Canterbury also faced a severe drought. This put a great deal of financial pressure on many farmers. Dairy product markets, and accordingly milk payouts, were affected but recovered relatively quickly. The development of dairying in the South Island, onto what had been sheep and beef country followed. In North and MidCanterbury dairy farming developed on the light soils, which was made possible through irrigation.

The dairy farms in the Amuri were developed as "milking platforms", with all young stock and replacement stock carried off the farm. This has meant that the Amuri area has always had very high production per cow and per hectare.

For the time, the early developments were often very large dairy farms. This reflected the large blocks of land in the area. Often the management skills and experience to run these operations well were lacking. There were many highly indebted and relatively inexperienced farmers in the Amuri area during the early stages. Poor employment relationships often resulted, with high staff turnover, unhappy staff and the sharemilkers staying no longer then they had to. The Amuri was often seen as a first stop for North Island dairy farmers and sharemilkers moving south. These people had no experience with large herd operations, further worsening the situation.

The result was that the entire region developed a bad reputation as somewhere to live and work. There were examples of farm operations with greater than $100 \%$ staff turnover within a season, and they 'achieved' this most seasons. An example of this is a person with whom I 
worked. He and his partner had been the 34th and 35th employees on one large dairy operation in one season. These were not the majority of employers, but they were the ones whose 'legend spread'. The result was a real problem attracting and retaining good staff in the Amuri area, for all employers. This problem was the motivation behind the initiation of the Amuri Dairy Employers Group (ADEG).

\section{Amuri Dairy Employers Group}

The Amuri Dairy Employers Group developed from the concern several dairy employers in the area had about the effect of the 'staff shortage' on their farm performance. This concern came from people, some who had been in the Amuri area sometime, and others, who had just moved into the area. These people found the relative unavailability of staff a real problem for their businesses. These farmers put together a proposal to address the labour problems, and called a public meeting to discuss it. The meeting was held on $2^{\text {nd }}$ May 2000, "to discuss the labour problem". 42 of the 45 farms in the area were represented at the meeting. During the meeting a draft proposal was put forward, including a Constitution and a Code of Practice. These were all up for discussion to reach general agreement. The draft Code of Practice contained:

$>$ A proposed 50 hours per week limit on hours worked by under 18 year olds

$>$ Rules on minimum standards regarding accommodation

$>$ A maximum of 12 consecutive days worked, with at least 2 consecutive days off to follow.

$>$ An employee had to have an employment contract and job description, and was to be allowed to see the contract for a minimum of 24 hours before having to sign it, (this was before ERA 2000).

$>$ It was up to the employer to ensure that the employee had the required life skills to look after him/herself, e.g. issues like a healthy diet, cooking, budgeting etc.

In the original 'discussion' version of the Code of Practice, the 50 hours per week maximum applied to under 20-year olds. It was lowered to 18 years of age prior to the first public meeting.

Most of these rules were considered acceptable. The main "bone of contention" was the limit on hours of work by young staff. People who employed young staff, and had no problem retaining them, and therefore felt that their practices worked fine, objected to the limitations this rule imposed on their businesses. Two key issues were raised in the 'robust discussion' which surrounded this proposal; the 50 hour per week limit was not workable, as many employers had their staff, and 'wage budgets' set for the coming season, and could not make the adjustments required to accommodate 50 hour weeks from the under 18 's. The other issue raised was that many of the members were sharemilkers and would have to bear the cost of any increase in accommodation required to handle more staff working fewer hours.

The Constitution presented contained some key points: all members had to agree to; undertaking mandatory annual employer training; displaying the code of practice in the work place; a list of 'contact people' for the staff regarding employment problems; providing employee training; and an emergency labour list.

At the meeting a few of the finer points were discussed at length and some quite loudly, with some revisions suggested. The general guidelines were accepted by most of those who wished to be involved by the end of May 2000 .

The 50 hours per week working limit was removed and replaced with 'up to 50 hours' and an agreement to provide meals each day of the work period for which the 50 hour limit was exceeded. An agreement was reached to 'try and limit hours to 50 hours per week', and for this point to be reviewed later.

The Amuri Dairy Employers Group has the following stated aims:

$>$ To function as a group of high calibre employers who promote the Amuri Dairy Employers group as such. Staff and employer training are deemed integral to this role.

$>$ To promote the Amuri dairy industry as a positive career choice and an attractive employment option.

$>$ As a secondary function a dairy employer network offering local area industry support.

From this meeting initial employer training was set up. It began on 12 June 2000; also the employee training was started. Over the winter period a life-skills course was run. This covered basic 'well-being' issues including; budgeting, cooking, sewing, and eating well. Many of the employees are young single males who have just left home and lack some of these skills. This shows that the ADEG was always looking at issues beyond just staff performance and was focused on staff well being. Since that time, ADEG has run many courses on what you may consider the basic skills and husbandries related to agriculture. For example; pasture scoring, condition scoring, animal health, motorbike safety, chainsaw courses, and a communication course for the senior managers. The employer members should have attended three employment management courses. There have also been many social functions for both employees and employers, some joint and some separate events. The ADEG put on a 'welcome' for the new people to the area and a 'farewell' for those leaving. This is seen as an important community activity that was otherwise lacking. Members who had agreed to membership and paid their subscription in the early stages, and now only those who have passed the audit and paid their sub are able to advertise with the Amuri Dairy Employers Group logo (see below). 
Figure 1 - Amuri Dairy Employers Group Logo

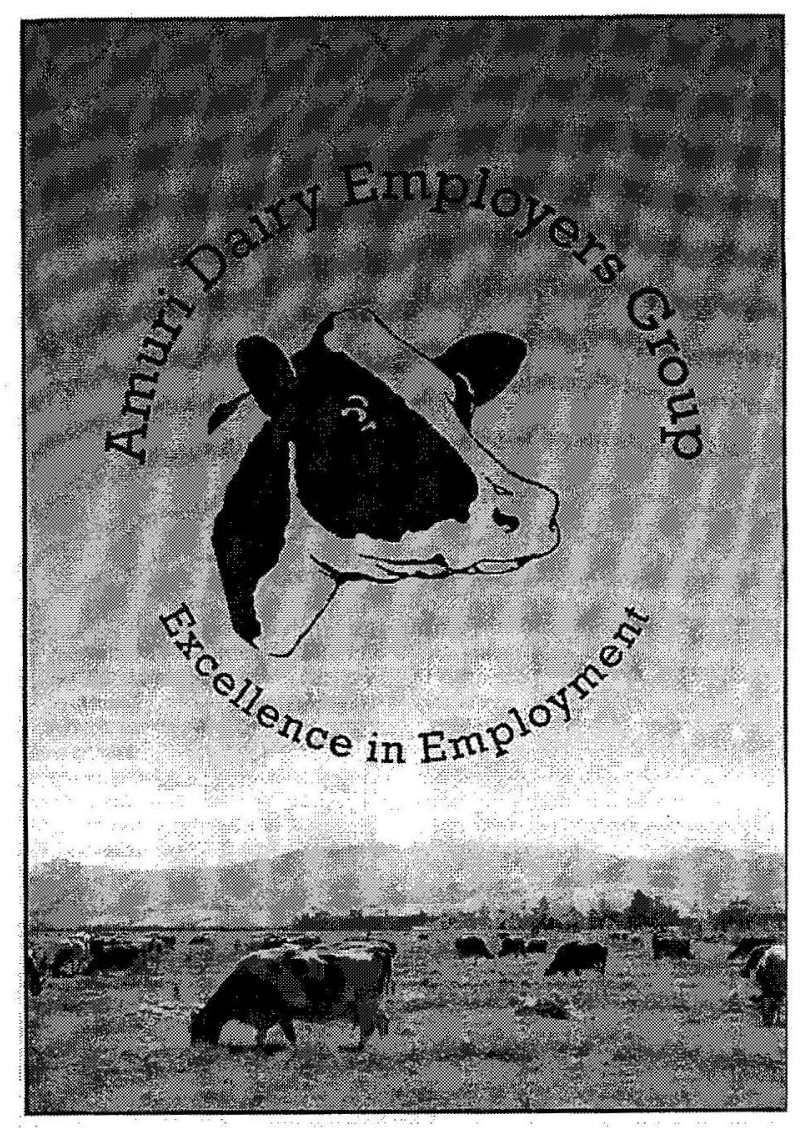

After some discussion as how best to go about the 'audit' of employment practices as was felt necessary to give the group creditability, Investors In People NZ were contracted to perform an audit against the Code of Practice requirements. The development of the ADEG is shown on a timeline, Figure 3.

\section{My Study}

The research was carried out following a case study methodology. Several sources of data were used including; official statistics, interviews with ADEG members and employees of members, and other background literature, and an anonymous survey of employees.

All current members, 29 and 18 respectively as at winter, 2001 and 2002, were interviewed. Also I interviewed 20 employees of ADEG members. This was supplemented by an anonymous survey of employees during the winter of 2001 , to which I received 20 replies. I also spoke with some 'key' members of the Amuri community, many of whom had been in the area prior the establishment of the irrigation schemes.

I interviewed ADEG members regarding: their perception of the group and its performance against its stated aims, employee and employer training provided; difficulties they foresaw for the group; and what effects the group had on Amuri area. In the second year interviews with the long-term ADEG members, I also asked questions regarding changes in employer practices they had made, the drivers of these changes, their effects, benefits gained and a series of questions regarding the employment practice audit.

Another nine members who had joined the group since the first winter were interviewed. I asked them questions regarding what effects the ADEG had on their employment practices; what it was like moving into area with such a group, what expectations they felt there were regarding employment practices in the area, and what if anything could have been done to encourage them to have joined the group earlier.

I spoke with the employees during the early winter of 2002 . I tried to gain from them their 'sense of job satisfaction', what issues were important to them in job satisfaction, what effect ADEG has had on their employment conditions, and the employment conditions generally in the Amuri area.

As there is very little information on employment standards and practices in the dairy industry, the study is very much a qualitative study, and attempts to describe what happened and how it was done. The study cannot be statistically validated. There are no figures against which I can compare statistics gathered from the ADEG.

\section{The Results - Employees}

In relation to the employees, the group has had a very positive effect. However, from the employee's perspective the group has had no effect. That is, that the employees I spoke with were generally very happy with most aspects of their jobs, and saw almost no correlation between their job satisfaction, employment conditions, and the efforts of ADEG. The employees considered that employment conditions in the Amuri area both within and outside the employers' group had significantly improved in the last two years. Housing, hours worked, and time off, were the primary factors, which the ADEG members employees identified as having improved. The increase in social interaction among farm staff and the increased availability of training in the Amuri were the only two factors which employees themselves identified as a benefit to them resulting directly from ADEG. It was felt by several employees that the group was an "employers group" and was seen as something of an old boys club, and not particularly friendly towards employees. This seems to stem primarily from the agreed 'complaints procedures' not being followed, and those activities that were provided by ADEG not being clearly identified. As approximately 32 of the farms in the area are involved with ADEG it becomes hard to differentiate what is ADEG and what is not. The ADEG provide staff only discussion groups, to encourage staff participation. The same people who run the general discussion groups, which are open to the entire community, often run these discussion groups. Hence the potential for confusion. 
Employers identified many benefits in belonging to the ADEG. Some of these are summarized in Tables 1 through 7 . In the year between the interviews, the variation in group members' opinions had reduced significantly. Most of the members saw it as important to maintain the group in the future, but suggestions as to how this could be best achieved, varied widely. The ADEG committee is currently working on a full business plan for the group. In working through this hopefully a consensus or at least a common vision can be achieved. It was believed widely that the committee had done very well in getting the group up and running. The need to set policies and structures in place to ensure that the group is ongoing and the enthusiasm is maintained was the primary concern of $\mathrm{ADEG}$ members in 2002 .

I asked members what effect ADEG has had on their employment practices. Many consider it has had little effect and that their employment practices were above the code of practice level. Some others, who again considered that their practices were above code of practice level anyway, felt that they had gained an increased awareness of the important factors in employment relationships. The employer training was found to have been useful to all members, and how useful was related to the employers' levels of experience and previous training in employment matters.

In 2001 a major concern of group members was a lack of credibility of the group given the audit process had yet to be established. However in 2002, the audit process is established, most members consider the group is now entirely credible. Some member's still held concerns about the employment practices of some of the other members. These members are meeting the minimum requirements, are complying with the code of practice, but by many are still considered to be poor employers. The ongoing problems generally stem from issues of communication and organisation.

The results of the questions regarding employers' perceptions of the groups performance against it aims are as follows.

(N/A is recorded for No Answer and Not Applicable).

Do you consider the Promotion of the Group, as Good Employers has been Effective (1 Very Effective through 5 Very Ineffective)?

\begin{tabular}{|c|c|c|}
\hline & $\mathbf{2 0 0 1}$ & $\mathbf{2 0 0 2}$ \\
\hline Yes & 22 & 18 \\
\hline No & 2 & 0 \\
\hline N/A's & 5 & 0 \\
\hline$\%$ Support & 91.67 & 100.00 \\
\hline
\end{tabular}

Do you consider the Promotion of the Dairying as a Career by the Group, has been Effective (1 Very Effective through 5 Very Ineffective).

Table 2 Promotion of Dairying as a Career

\begin{tabular}{|c|c|c|}
\hline & $\mathbf{2 0 0 1}$ & $\mathbf{2 0 0 2}$ \\
\hline Yes & 25 & 18 \\
\hline No & 3 & 0 \\
\hline N/A's & 1 & 0 \\
\hline \% Support & 89.29 & 100.00 \\
\hline
\end{tabular}

Do you consider the Promotion of the Amuri Region, as somewhere to live and work has been Effective? (1 Very Effective through 5 Very Ineffective)?

\section{Table 3 - Promotion of Amuri Region}

\begin{tabular}{|c|c|c|}
\hline & $\mathbf{2 0 0 1}$ & $\mathbf{2 0 0 2}$ \\
\hline Yes & 21 & 18 \\
\hline No & 4 & 0 \\
\hline N/A's & 3 & 0 \\
\hline \% Support & 84.00 & 100.00 \\
\hline
\end{tabular}

At the time of the first interviews the group had been in operation, slightly over a year, yet it was the opinion of most group members, that these aims had been met. By the second year, members were unanimous in their support of the group achieving these aims.

Do you consider there are advantages to you advertising for staff as a member of the Amuri Dairy Employers Group (Yes/No).

\section{Table 4 Advantage Advertising as ADEG member}

\begin{tabular}{|c|c|c|}
\hline & $\mathbf{2 0 0 1}$ & $\mathbf{2 0 0 2}$ \\
\hline Yes & 19 & 15 \\
\hline No & 5 & 0 \\
\hline N/A's & 5 & 3 \\
\hline \% Support & 79.17 & 100.00 \\
\hline
\end{tabular}

With just one year of marketing and having the logo, most members in the first and all members by the second year, considered that there were advantages to them advertising for staff as a member of ADEG. 
Could you please give each of the following factors a 1 (very much improved) through 5 (not at all Improved) rating.

\section{Table 5 Ratings of Improvements Observed in Many Factors due to the Amuri Dairy Employers Group}

\begin{tabular}{|r|c|c|}
\hline & \multicolumn{2}{|c|}{ Year } \\
\hline Means of Ratings & $\mathbf{2 0 0 1}$ & $\mathbf{2 0 0 2}$ \\
\hline Time to fill vacancies & 2.26 & 2.77 \\
\hline $\begin{array}{c}\text { Numbers of Respondents } \\
\text { to Employment Opportunities }\end{array}$ & 2.26 & 2.83 \\
\hline Fewer vacancies arising & 2.19 & 1.75 \\
\hline $\begin{array}{c}\text { Quality of respondents } \\
\text { To employment opportunities }\end{array}$ & 2.32 & 2.79 \\
\hline Skills of respondents & 2.32 & 2.63 \\
\hline Attitude of respondents & 2.09 & 2.07 \\
\hline
\end{tabular}

"Fewer vacancies arising" was felt to have been an effect in 2001, and to have been even more pronounced in 2002. Almost all the other topics were less well 'supported' in 2002. I think most of this can be explained by members increased expectations and standards. Given the efforts put in and training received by ADEG members, they now expect better from both current and potential staff.

Do you consider that the Amuri Dairy Employers group has had a Positive Effect on the Employment situation?

Table 6 Positive Effect on Employment Situation

\begin{tabular}{|c|c|c|}
\hline & $\mathbf{2 0 0 1}$ & $\mathbf{2 0 0 2}$ \\
\hline Yes & 25 & 17 \\
\hline No & 3 & 1 \\
\hline N/A's & 1 & 0 \\
\hline \% Support & 89.29 & 94.44 \\
\hline
\end{tabular}

Although not complete, the overwhelming majority of ADEG members felt that the ADEG has had a positive effect on the employment situation in the Amuri.

Do you consider that the Amuri Dairy Employers Group has had a Positive Effect on your Existing Staff? (Table 7 , next column).

Not quite unanimous, but again most members felt that through the training and, increased social interaction between staff, that ADEG has had a positive effect on their staff. Another point raised by many employers was the 'motivational effects' of their staff seeing the employers providing training for them, and being asked their opinions by people as part of the audit process and as part of this research. It has all added to the staffs' sense of value and self worth.
Table 7 Positive Effect on Existing Staff

\begin{tabular}{|c|c|c|}
\hline & 2001 & 2002 \\
\hline Yes & 19 & 15 \\
\hline No & 6 & 2 \\
\hline N/A's & 3 & 1 \\
\hline \% Support & 76.00 & 88.24 \\
\hline
\end{tabular}

\section{Discussion}

The aspects of employment relationships covered by the ADEG code of practice, are such that an employer could meet all requirements, and their staff could still be unhappy. The issues of 'basic respect', ensuring that the employees feel motivated, involved and valued within the operation, are far more complex management issues. They are not covered by the current code of practice. With the increased discussion and raised awareness of important employment relationship issues, positive changes have occurred to the core values of members. Many aspects of what ADEG provides have contributed to this; the audit and associated discussion with an employment relationship expert; the thinking triggered by the "self assessment form"; open discussion amongst members; and even discussion with me on employment issues, have all been factors.

Discussion among ADEG members was found by many to have been beneficial, and more of it was a recommendation from many members in 2002.

After all this training, learning and discussion, a wide variation in points of view, motives, and opinions still exist. There are people who became part of this group for little more than, "wanting to be seen as being supportive of the group"; some who saw that their employment practices could be improved; and some who wanted an increased supply or availability of staff for purely economic reasons. Those who joined just to be 'supportive' left the group prior to the audits being carried out, but all the other points of view still exist. Yet much has been achieved. The concern looking to the future is that people who have achieved what they expected are not motivated to push on with the group. It took great passion, effort and belief to get the group started and to where it is. Without this same motivation going forward, this could be a real problem.

It comes down to a matter of expectation. The drive and enthusiasm to get the groups started and developed came largely from people whose expectations have not been met. As these people step away from driving the group, the lesser expectations of those taking over may become a limiting factor. Many see maintenance of the group, and if necessary some 'tightening of the rules' to maintain a competitive advantage, as all that is necessary. Others consider that the group should continue to push on and try to raise standards. Finding a workable middle ground is the key to the future of the group. The business plan being developed currently will play a key role in gaining agreement on these issues. It is important to note that the input required of an 'average' (non-committee) member of the group so far has been 
minimal. Membership has cost them $\$ 350$. They have had to undergo 3 training courses, and attend some of the meetings held, and allow their staff to attend training, not a huge workload or required input, given what has been achieved.

The 'stigma' of employee turnover has been reduced, with people in the Amuri now more willing to talk about employment issues, and not being afraid to lose or replace a staff member if it is not working out. It may sound contradictory to be encouraging turnover, but in some cases, replacing a 'problematic' or unsuitable employee may often result in positive outcomes for the employer and remaining employees. An important issue in this regard was the increased importance members put on 'employee fit' with the other employees and with the position available. Formerly people in the Amuri previously have had a "we'll take who we can get, and make them fit..." approach. The members, as a result of the training in these matters and an increased confidence in being able to attract and then select someone suitable, now formally define the position available, and what attributes someone to fill it must have, and wait to get someone who meets those requirements. The occurrences of 'just putting up with someone' until the end of season', or ' until we're through the worst of it' would seem to be significantly reduced.

11 of the 18 members interviewed were Sharemilkers, and one was a contract milker. These are 'categories' of employers who tend to consider they have limited options in terms of staffing policies, due to their situation, both financially and in terms of having to work with what is provided by the farm owner. Despite $66.7 \%$ of members of the ADEG being in this position, much has been achieved. This shows that there are many factors significant to employee satisfaction, which is within the realms of an employer's control. For example, the inability to provide a better house or bigger shed need not prevent an employer providing an attractive job to staff. It would appear people are overcoming, "well. I'm only a sharemilker, I can't do anything about...." to implement these improvements.

The intentions or planned direct effects of ADEG against the HCF are illustrated in Figure 4. These are indicated on the above diagram by the Rectangles. The effects of the ADEG went well beyond those anticipated by this researcher. The 'unplanned' effects are indicated by the Ovals. In relation to Capacity these are: time spent by people with friends or family onfarm learning skills they otherwise would not have; and the community's much more positive perception of dairying as a career, leading to more local people entering the industry than previously. In terms of Matching, all has gone pretty much according to expectation. The unplanned effects related to Opportunity in the HCF, have been; the support that the ADEG has received from the business community, resulting in referrals from professionals regarding employment. Both land agents and the rural lenders considering that the groups' existence is positive in relation to clients. The ADEG has also attracted a lot of sponsorship, allowing the provision of much training at little cost to members. The early employer training and initial employment practice audits were conducted at minimal cost to the group, with the organisations keen to become involved with the ADEG.

\section{Figure 2. Human Capability Framework}

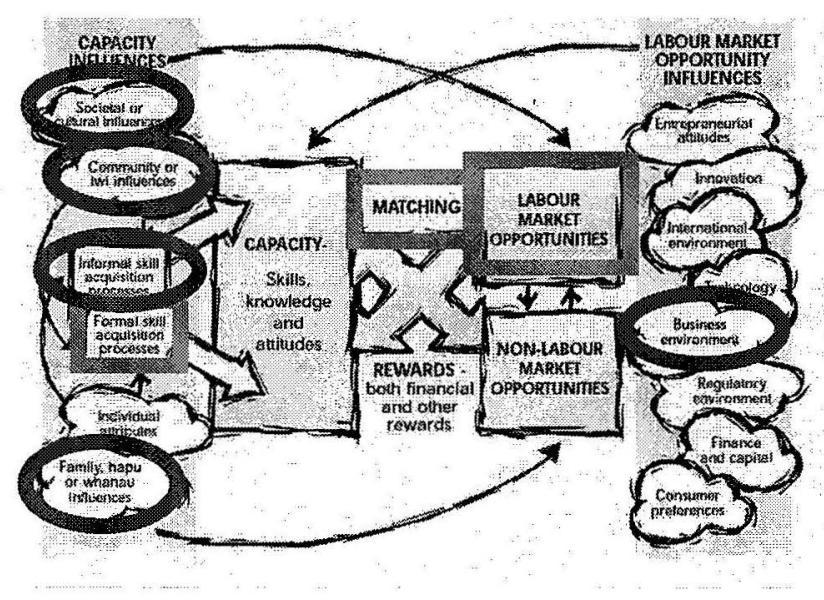

\section{Conclusions}

The Amuri Dairy Employers Group is a valuable organisation in terms of dairy farming employment issues.

\section{The Amuri Dairy Employers Group:}

$>$ Made employer training readily available to its members

$>$ Set dates and deadlines to do certain things (i.e. review contracts, up-grade the house etc), perhaps 'closing the gap' between intent and action.

$>$ Provided a forum for discussion about employment issues.

$>$ Changed dairy farmers core employment values in a positive way.

The 'core functions' and activities, which have resulted in much of the change observed, could be replicated without the need for the full group. However, ADEG's success must be attributed to its dairy farmer members who had vision of better dairy farm employment relationships. 
Figure 3. Timeline of the Amuri Dairy Employer Group

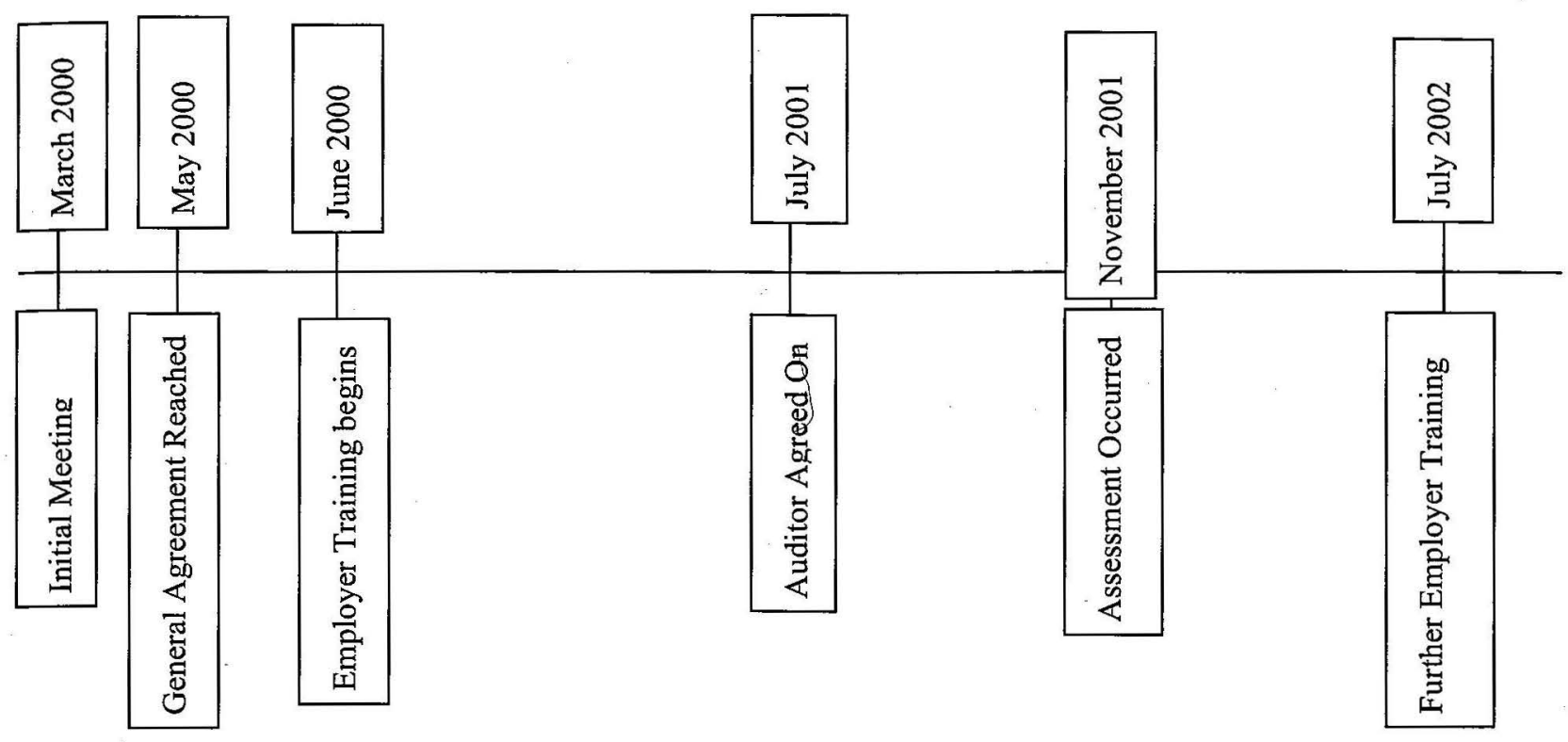

\section{References}

Fonterra (2002) About new Zealand (Online). Available http://www.fonterra.com/content/dairyingnz/about nz/default.jsp (2002, November 20).

Holmes, C. and Cameron, K. (2001). High Merit "People-Replacements", The Foundation of Future Success on Dairy Farms. Ed. Brookes, I.M. Dairy Farming Annual 2001, Volume 53. Massey University, Palmerston North, New Zealand.

Gaul, P. (2000). South Island Dairying - 2005. Ed. Elvidge, D. Healthly Wealthy and Wise, South Island Dairy Event Proceedings 2000, 5 to 7th July 2000, Ascot Park Hotel, Invercargill. Wyatt and Wilson Print, Christchurch, New Zealand.

\section{Notes}

1. All ADEG members must volunteer their services (not their employee's) for the Emergency Labour List so that if another member is suddenly short staffed, they have people to phone to provide shortterm cover. Several very early morning phone calls have been made following car crashes involving employees. Previously in this situation, there were very few options available to an employer. This policy reduces both stress on all parties in event of an accident, and reduces the employers' sense of isolation 